\title{
Pengembangan Media Pembelajaran Termoelektrik Generator sebagai Sumber Energi
}

\author{
Nur Tri Yono ${ }^{1, a)}$, Mangasi Alion Marpaung ${ }^{2, b)}$ Desnita $^{2, c)}$ \\ ${ }^{1}$ Magister Pendidikan Fisika FMipa UNJ, Jln Pemuda No. 10 Jakarta 13220 \\ ${ }^{2}$ Prodi Pendidikan Fisika FMIPA UNJ, Jl. Pemuda No 10, Jakarta 13220
}

Email: a)nurtrinunu@hotmail.com, ${ }^{\text {b) }}$ mangasi@unj.ac.id, ${ }^{c}$ desywaznadil@gmail.com

\begin{abstract}
This research is aimed to develop the experimental instrument that is thermoelectric generator as the instructional media for energy resource. Used Research Development method with ADDIE (Analyze - Design - Develop - Implementation - Evaluation) models. The media is designed and developed by using Solid Works app. This media is equipped with screen, so the temperature value, electric current, and voltage that produced by the experiment will appear on it. Beside that, this media is user friendly for student because they no need to assemble this instrument, and also the measurement is accurate because this instrument is digital based. This media has been validated with the media experts and subject matter experts. The result is showing that thermoelectric generator is worthy to use as instructional media for energy resource subject in senior high school grade 3 .
\end{abstract}

Keywords: instructional media, termoelectric generator, ADDIE models.

\begin{abstract}
Abstrak
Penelitian ini bertujuan untuk mengembangkan media pembelajaran yaitu berupa alat praktikum termoelektrik generator sebagai sumber energi. Metode penelitian yang digunakan adalah research and development (R\&D) menggunakan model ADDIE (Analyze - Design Develop - Implementation - Evaluation). Media didesain dan dikembangkan dengan menggunakan aplikasi Solid Works. Media ini dilengkapai dengan layar yang dapat menampilkan besaran suhu, kuat arus, dan tegangan yang dihasilkan dari suatu termoelektrik, selain itu media ini mudah untuk digunakan karena peserta didik tidak perlu merakit dari awal dan pengukuran lebih presisi karena berbasis digital. Media yang dikembangkan telah divalidasi oleh para ahli media dan ahli materi pembelajaran. Hasil validasi tersebut menunjukkan bahwa termoelektrik generator layak digunakan sebagai media pembelajaran pada pokok bahasan sumber energi di kelas XII MIA.
\end{abstract}

Kata-kata kunci: tuliskan kata-kata kunci tidak lebih dari satu baris.

\section{PENDAHULUAN}

Pembelajaran merupakan sebuah proses yang sangat penting dalam kegiatan penyampaian informasi dalam pendidikan. Untuk pembelajaran yang tidak semata-mata dapat ditransferkan melalui transaksi informasi saja, seperti pembelajaran fisika, tentu pemahaman yang mendalam hanya dapat terjadi melalui latihan keterampilan dan melalui pengalaman. Penyampaian 
pembelajaran fisika harus sedapat mungkin membawa peserta didik kedalam kehidupan nyata untuk itu diperlukan media pembelajaran lain yang lebih kongkrit yaitu berupa alat praktikum (Syarifuddin 2010).

Alat praktikum dalam pembelajaran fisika dapat digunakan sebagai media untuk demonstrasi maupun eksperimen. Demonstrasi dan eksperimen merupakan cara mengajar dimana peserta didik diajak untuk melakukan serangkaian percobaan dengan mengalami dan membuktikan sendiri sesuatu yang diajarkan secara teori. Ketika peserta didik melakukan percobaan di laboratorium, mereka memperoleh pemecahan masalah dan penelitian keterampilan serta memiliki sikap positif terhadap sains (Popescu \& Morgan, 2007).

\section{METODE PENELITIAN}

Penelitian ini merupakan adalah penelitian dan pengembangan (research and development) dengan model ADDIE. Model tersebut memiliki lima tahap yaitu, Analyze, Design, Develop, Implement, Evaluate (Branch 2009).

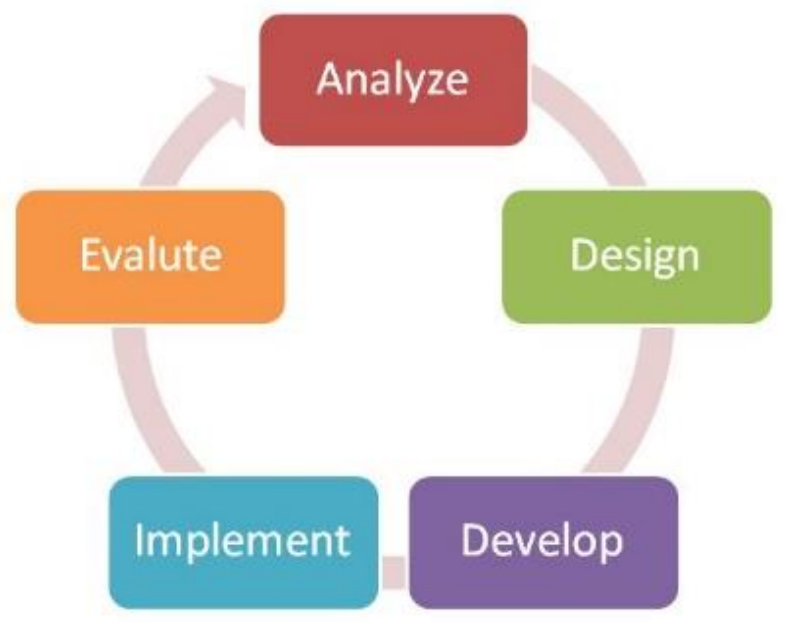

GAMBAR 1. Tahap Pengembangan Model ADDIE

Pada tahap analyze atau analisis ini terdiri dari analisis kebutuhan, analisis kurikulum dan analisis materi pelajaran. Berdasarkan hasil analisis kebutuhan yang dilakukan kepada pendidik fisika SMA. Dari enam responden pendidik fisika SMA ternyata $66.66 \%$ responden hanya menggunakan buku teks saja dalam mengajar mata pelajaran fisika. Fakta tersebut menunjukkan bukti pula bahwa 100\% responden hanya menjelaskan teori-teori saja untuk materi sumber energi. Bahkan sebanyak 83,33\% responden merasa kesulitan dalam menjelaskan materi sumber energi. Padahal $100 \%$ dari mereka mengakui bahwa peserta didik lebih antusias apabila dijelaskan dengan menggunakan media pembelajaran lain.

Pada tahap design dan development, desain awal dibuat dalam bentuk tiga dimensi berupa gambar yang kemudian dikonsultasikan dengan dosen pembimbing agar dapat diberi masukan tentang desain yang akan dikembangkan sehingga kedepan tidak terjadi ketidaksesuaian antara peneliti dan pembimbing.

Selanjutnya rancangan produk direalisasikan, yaitu membuat alat praktikum generator termoelektrik sebagai media pembelajaran untuk peserta didik yang dikembangkan berdasarkan pada penelitian pendahuluan dan perencanaan.

Pada tahap selanjutnya yaitu implement atau implementasi Di tahap ini produk yang telah divalidasi oleh ahli media dan ahli materi diujicobakan kepada peserta didik. Uji coba dilakukan kepada peserta didik peminatan MIA di SMAN 31 Jakarta dan SMAN 20 Jakarta. 
Tahap kelima yaitu evaluate atau evaluasi. Di tahap ini alat praktikum termoelektrik generator yang telah diimplementasikan kepada peserta didik mendapatkan umpan balik berupa komentar dan saran baik dari peserta didik dan juga dari pendidik. Selanjutnya dilakukan revisi kembali hingga menjadi produk yang layak dan lebih baik.

Teknik analisis data dari angket uji validasi dinilai menggunakan penilaian skala Likert poin 1 sampai 4 sebagai berikut (Sugiyono 2007):

TABEL 1. Skala Likert untuk Penilaian

\begin{tabular}{clc} 
No & Alternatif Jawaban & $\begin{array}{c}\text { Bobot } \\
\text { Skor }\end{array}$ \\
\hline 1. & Sangat Setuju & 4 \\
\hline 2. & Setuju & 3 \\
\hline 3. & Tidak Setuju & 2 \\
\hline 4. & Sangat Tidak Setuju & 1 \\
\hline
\end{tabular}

Selanjutnya hasil penelitian validasi dihitung dengan cara sebagai berikut

$$
\text { persentase skor }=\frac{2 \text { skor perolehan }}{\sum \text { skor maksimum }} \times 100 \%
$$

Persentase skor yang diperoleh selanjutnya diukur dengan menggunakan interpretasi skor untuk skala Likert, yaitu sebagai berikut:

TABEL 2. Interpretasi Skala Likert

\begin{tabular}{cc}
\hline Persentase & Interpretasi \\
\hline $0 \%-25 \%$ & Sangat Tidak Baik \\
\hline $26 \%-50 \%$ & Tidak Baik \\
\hline $51 \%-75 \%$ & Baik \\
\hline $76 \%-100 \%$ & Sangat Baik \\
\hline
\end{tabular}

\section{HASIL DAN PEMBAHASAN}

Berikut ini adalah tampilan dari alat peraga termoelektrik generator:

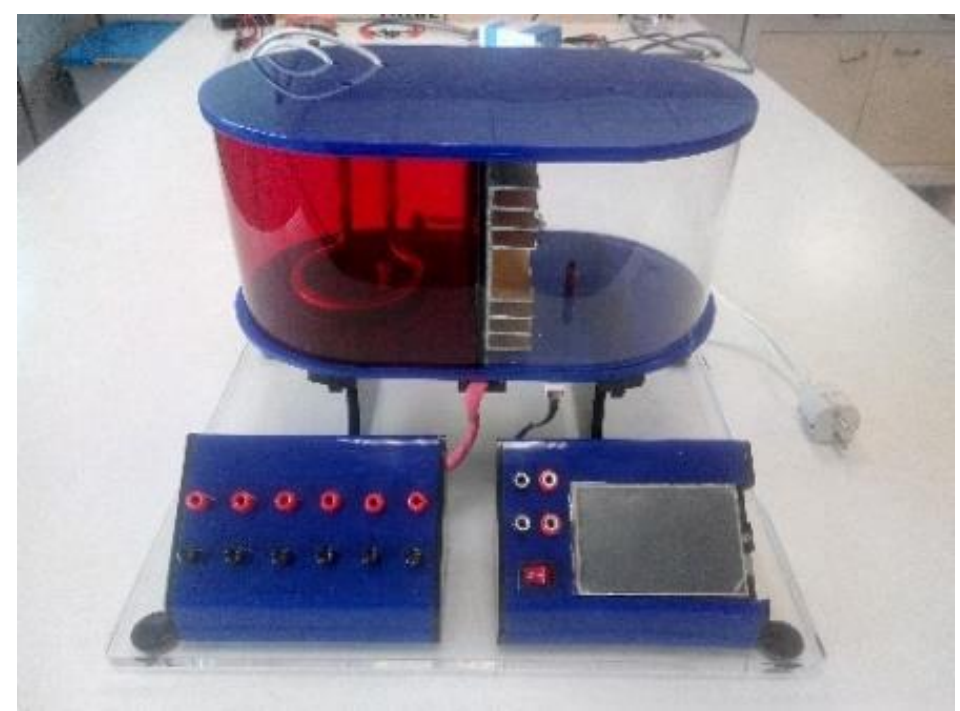

GAMBAR 2. Tampilan depan alat praktikum termoelektrik generator. 


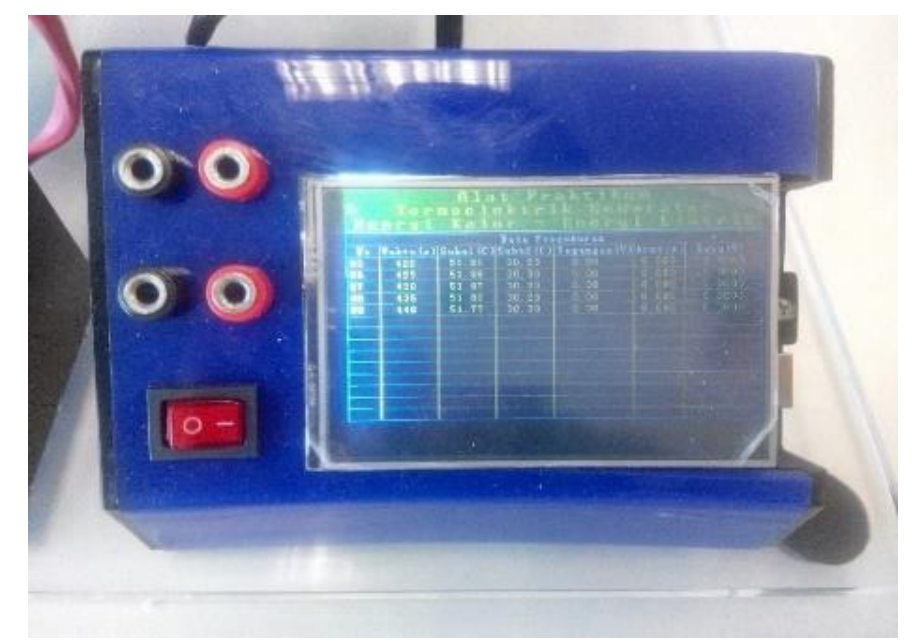

GAMBAR 3. Tampilan layar LCD alat praktikum termoelektrik generator.

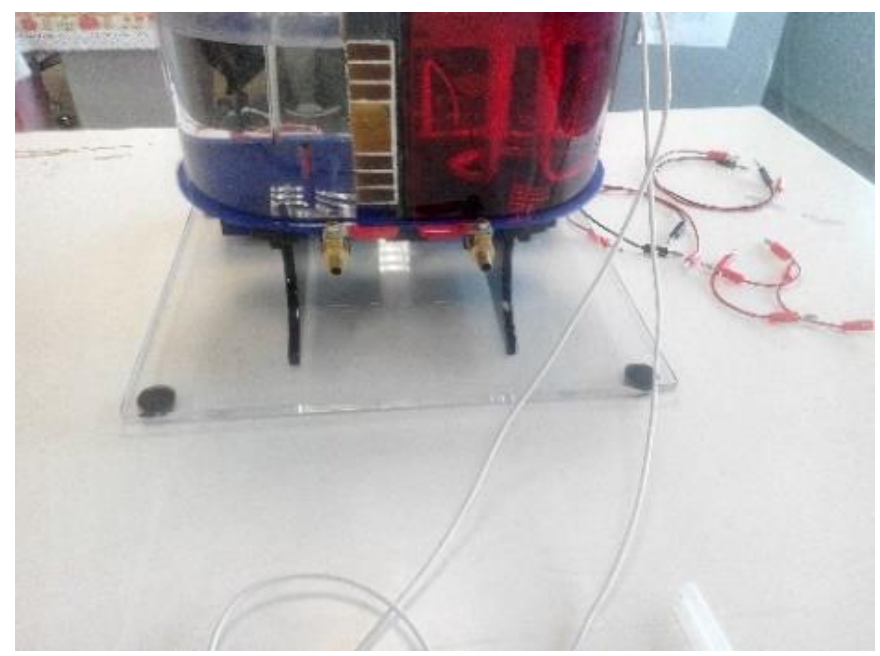

GAMBAR 4. Tampilan belakang alat praktikum termoelektrik generator.

Untuk kegiatan eksperimen, alat praktikum termoelektrik termogenerator dilengkapi dengan buku paduan set eksprimen dan lembar kerja siswa yang berisi petunjuk penggunaan, prosedur dan kegiatan praktikum.
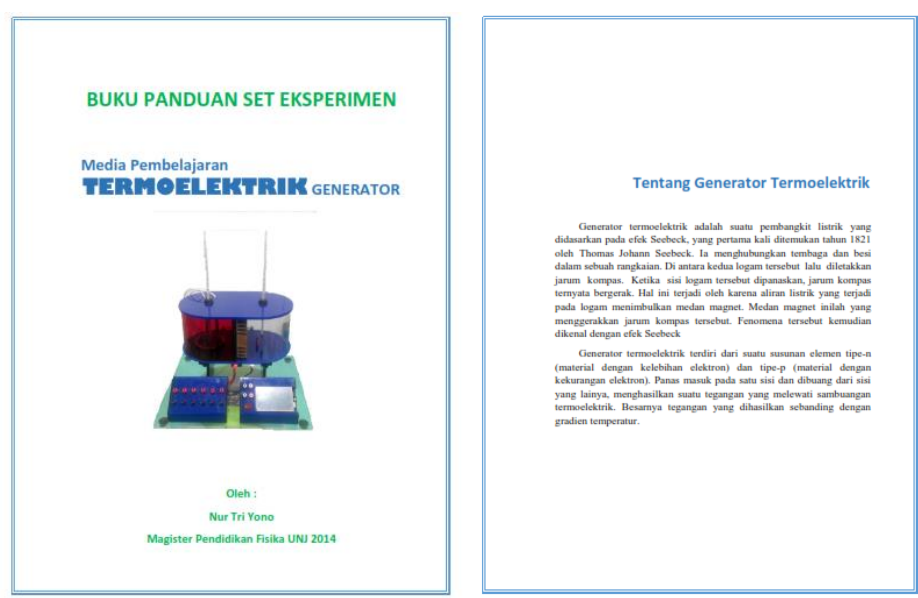

GAMBAR 5. Tampilan buku panduan set eksperimen termoelektrik generator. 
Berdasarkan hasil uji validasi media, pembelajaran, dan materi oleh para ahli, didapatkanlah hasil sebagai berikut:

TABEL 3. Hasil Uji Validasi

\begin{tabular}{ccc}
$\begin{array}{c}\text { Uji } \\
\text { Validasi }\end{array}$ & Persentase & Interpretasi \\
\hline Ahli Media & $89,1 \%$ & Sangat Baik \\
\hline Ahli Materi & $94,6 \%$ & Sangat Baik \\
\hline
\end{tabular}

Hasil uji validasi set eksperimen termoelektrik generator oleh ahli media menunjukkan persentase capaian sebesar $89,1 \%$ dengan interpretasi sangat baik pada semua aspek media. Hasil uji validasi set eksperimen termoelektrik generator oleh ahli materi menunjukkan persentase capaian sebesar 94,6\% dengan interpretasi sangat baik pada semua aspek materi.

\section{KESIMPULAN}

Berdasarkan hasil validasi oleh ahli media dan ahli materi, dapat disimpulkan bahwa media pembelajaran yang dikembangkan yaitu set praktikum termoelektrik generator pada pokok bahasan sumber energi untuk siswa SMA kelas XII MIA telah memenuhi kriteria sangat baik dan layak digunakan sebagai media pembelajaran fisika.

\section{UCAPAN TERIMAKASIH}

Penulis mengucapkan terimakasih kepada pihak-pihak yang membantu dari mulai proses awal, pembuatan dan penelitian ini selesai.

\section{REFERENSI}

Branch, Robert Maribe. 2009. Instructional Design: The ADDIE Approach. New York: Springer.

Popescu, A. \& Morgan, J. 2007. Teaching Information Evaluation and Critical Thinking Skills in Physics Classes. The Physics Teacher. 45: 507 - 510.

Sugiyono. 2007. Metode Penelitian Pendidikan Pendekatan Kuantitatif, Kualitatif, dan R\&D. Bandung: Alfabeta.

Syarifuddin, dkk. 2010.Strategi Belajar Mengajar. Jakarta: Diadit Media. 
